\title{
Analysis on Land Outflow of Agricultural Transfer Population from the Perspective of Generational Differences
}

\author{
Yanbo Zhou \\ College of Economics and Management \\ Shenyang Agricultural University \\ Shenyang, China \\ Taoling Cheng \\ College of Economics and Management \\ Shenyang Agricultural University \\ Shenyang, China
}

\author{
Chao Zhang \\ College of Economics and Management \\ Shenyang Agricultural University \\ Shenyang, China \\ Xiaomei Cao \\ College of Economics and Management \\ Shenyang Agricultural University \\ Shenyang, China
}

\begin{abstract}
With the development of urbanization in China, a large number of rural labors transfer from department and industry within the agricultural system to the two or three industry. Thus, it is a powerful impetus to the rapid transformation and development of China's economy. However, most of the non-agricultural transfer of Chinese rural labor is to retain the transfer of land. In this paper, investigating and analyzing the characteristics and differences of land transfer, such as the motivation of the land transfer, the object of the outflow, the time of the outflow, the form of outflow, the expectation of the outflow and so on, from the first generation and the new generation of agricultural transfer population to provide theoretical basis and practical reference for the policy decision of the relevant government departments.
\end{abstract}

Keywords-agricultural transfer population; land outflow; generational differences

\section{INTRODUCTION}

With the development of urbanization in China, a large number of rural labors transfer from department and industry within the agricultural system to the two or three industry. From the perspective of optimizing the allocation of resources, the peasant migrant worker is an important way to increase their income, to reduce the urban-rural income gap. It has played a huge role in promoting the transformation from agriculture to modern agriculture in China. However, most of the non-agricultural transfer of Chinese rural labor is to retain the land, it is a kind of incomplete transfer. Therefore, only let contractual operation right of rural land transfer, people who don't want to land can easily work to earn a living in the city, then, others who want to land possible obtain again large scale land to develop agricultural appropriate scale of operation.

In 2001, Wang Chunguang who is a researcher firstly proposed the analysis of the differentiation of migrant

Sponsors: Liaoning Provincial Social Science Fund "land circulation management and appropriate scale management problem research (L13BJY044). workers from the perspective of generation. In 2010,the central first document firstly defined the concept of "new generation of migrant workers", which provided the better partition theoretical basis for the analysis of the influencing factors of the agricultural transfer of agricultural land outflow, that is, under the generational differences, the analysis of land outflow of agricultural transfer population. And many scholars have put forward that there is a generational difference for the two generation of migrant workers in rural land transfer. Therefore, the author chose to research and analysis the land outflow issue of the two generation agricultural transfer population from the perspective of generational differences. Such a division can be more targeted to promote the effective outflow of agricultural land.

\section{DATA SOURCES AND SAMPLE CHARACTERISTICS}

\section{A. Data Sources}

The data used in this study is obtained through field research, according to the needs of the study, since June 2014 ,it is got by conducting field research that is one to one questionnaire for agricultural transfer population of some parts of Liaoning Province. In order to make the data obtained by this research can be true, reliable and to reflect effectively the basic situation of agricultural transfer population, the survey is as far as possible distributed in different urban and rural areas. So in the aspects of area selection, we selected Shenyang, Tie ling, Liaoning and other cities and their subordinate rural areas as locations obtained random samples. Totally 243 questionnaires were sent out and 205 valid questionnaires were returned. Because of the limitation of traditional customs in our country, unmarried children shall not have the right to arrange freely their agricultural land. Therefore, the respondent whose age is limited in the female for 70-20 years old and the male is 
70-22 years old, is rural labor force completed the employment who is urban migrant workers or others whose urban home have been transferred out the agricultural system. Restricted occupation types include unemployed the agricultural transfer population.

\section{B. Sample Characteristics}

Basic characteristics of agricultural transfer population.

In 205 agricultural transfer population randomly selected, there were 164 men and 41 women, accounting for $80 \%$ and $20 \%$ of the total sample respectively. It shows that men transferred from the agricultural system are the main people who are engaged in the two or three industry.

From the perspective of the age level of the agricultural transfer population, the average age of the respondents was 40.32 years old. It reflected at a certain extent that the transfer of the agricultural population in this age group has become a mainstay of the family and they must bear the burden of caring for the family. From the generation of view, it can be seen that there are 125 people in the first generation of agricultural transfer population and 80 people in the new generation of agricultural transfer population, accounting for $60.98 \%$ and $39.02 \%$ of the total sample respectively, and the first generation of agricultural transfer population is still the main group of the group.

From the perspective of the education level, the average schooling year of the sample was 9.46 years, there are 46 people in primary school and the below education level, 17 people in junior high school education level, 38 people in high school education level and 4 people in college education and above education level, accounting for $22.4 \%$, $57.1 \%, 18.5 \%, 2 \%$ respectively. Although the data shows that the average education level of agricultural transfer population has reached nine-year compulsory education, but the overall cultural quality of the agricultural transfer population is still on the low side in China.

To receive work-related training is that agricultural transfer population accepting skill training related work which is engaged in now. In "Table I", there are 65 people who have accepted related-work skill training and 140 people who didn't accept related-work skill training in 205 agricultural transfer population investigated, accounting for $31.7 \%$ and $68.3 \%$ of the total sample respectively. It shows that the industry in which the current agricultural transfer population is engaged is still low-skilled work. Its replacement rate is very low, and it reflects from the side that the working stability of the transfer of agricultural population is not high.

\section{The CURRENT SituATION ANALYSIS OF LAND TRANSFER OF AGRICULTURAL TRANSFER POPULATION}

\section{A. The Current Situation of the First Generation of Agricultural Transfer Population}

In the research process of the 205 effective questionnaires were collected, and in 205, the number of land out of the 120 people, the generation of agricultural transfer population of 65 people, the new generation of 55 people. Land did not flow out of the number of 85 people, of which a generation of 60 people, the new generation of 25 people. As shown in "Table I".

TABLE I. AGRICUltural LAND TRANSFER POPULATION OUTFLOW PRESENT SiTUATION OF STATISTICS

\begin{tabular}{|l|l|l|l|l|}
\hline \multicolumn{1}{|c|}{ Item } & A generation & $\begin{array}{c}\text { Percentage of } \\
\text { their respective } \\
\text { groups (\%) }\end{array}$ & $\begin{array}{c}\text { New } \\
\text { generation }\end{array}$ & $\begin{array}{c}\text { Percentage of } \\
\text { their respective } \\
\text { groups (\%) }\end{array}$ \\
\hline Land outflow & 65 & $52.00 \%$ & 55 & $68.75 \%$ \\
\hline $\begin{array}{l}\text { Land did not } \\
\text { outflow }\end{array}$ & 60 & $48 \%$ & 25 & $31.25 \%$ \\
\hline Total & 125 & $100 \%$ & 80 & $100 \%$ \\
\hline
\end{tabular}

1) Land outflow motivation: In the outflow motivation statistics, 120 of the land has been out of the transfer of agricultural population of 65 is a generation of agricultural transfer population, a total of 7 including the increase income, the pursuit of a new way of life, no time to take into account the land management, no interest in agricultural operations, others suggested that the outflow, there is a good policy guidance etc. In the field visits to the survey found that a generation of agricultural transfer of the population of the land out of the motivation is too busy to take into account the land management. "Table II"

TABLE II. LAND OUTFLOW MOTIVATION

\begin{tabular}{|l|l|l|l|}
\hline \multicolumn{1}{|c|}{ Item } & $\begin{array}{c}\text { Sample number } \\
\text { (person) }\end{array}$ & $\begin{array}{c}\text { The first } \\
\text { generation } \\
\text { (person) }\end{array}$ & $\begin{array}{c}\text { Proportion } \\
(\%)\end{array}$ \\
\hline Increase income & 6 & 4 & 6.15 \\
\hline Pursuit a new way of life & 18 & 7 & 10.77 \\
\hline $\begin{array}{l}\text { Have no time to take care } \\
\text { of the land management }\end{array}$ & 58 & 36 & 55.38 \\
\hline $\begin{array}{l}\text { No interest in agricultural } \\
\text { Management }\end{array}$ & 20 & 4 & 6.15 \\
\hline $\begin{array}{l}\text { Others suggested that the } \\
\text { outflow }\end{array}$ & 3 & 3 & 4.62 \\
\hline Have good policy guidance & 4 & 3 & 4.62 \\
\hline Other & 11 & 3 & 4.62 \\
\hline Total & 120 & 65 & 100 \\
\hline
\end{tabular}

36 agricultural transfer of population in 58, the choice of land outflow is too busy to take into account the land management, The number of a generation is more than the new generation, this may be because there are a lot of people in a generation is a pillar of the life of the family or as the backbone of the work, due to the dual pressures of life and work, therefore, no time to take into account the home land management.

2) Land outflow object: "Table III" statistics of land outflow objects shows that 120 of the land has been out of the transfer of agricultural population, of which 65 are a generation of agricultural transfer population, including four items of relatives and friends, fellow villagers, agricultural cooperatives, research institutes, large enterprises. Found in the filed visits to the survey that a generation of agricultural 
population transfer to the basic object of land outflow for relatives and friends, fellow villagers.

TABLE III. LAND OUTFLOW OBJECT

\begin{tabular}{|l|l|l|l|}
\hline \multicolumn{1}{|c|}{ Outflow object } & \multicolumn{1}{|c|}{$\begin{array}{c}\text { Sample } \\
\text { number }\end{array}$} & \multicolumn{1}{c|}{$\begin{array}{c}\text { A } \\
\text { generation }\end{array}$} & $\begin{array}{c}\text { Proportio } \\
\text { n (\%) }\end{array}$ \\
\hline Relatives and friends & 80 & 38 & 58.46 \\
\hline Fellow villagers & 25 & 18 & 27.69 \\
\hline Agricultural cooperatives & 2 & 2 & 3.08 \\
\hline $\begin{array}{l}\text { Research institutes and large } \\
\text { enterprises }\end{array}$ & 12 & 7 & 10.77 \\
\hline Other & 1 & 0 & 0 \\
\hline Total & 120 & 65 & 100 \\
\hline
\end{tabular}

There are 105 people's land transfer objects choose relatives and friends, fellow villagers, including a generation of 56 people, which may be because generation considering if the land is transferred to the relatives and friends or village people, may withdraw at any time. Therefore, the land outflow object mostly choose relatives, friends and fellow villagers.

3) Land outflow of fixed number of year: "Table IV" shows the statistics on the number of years of land outflow of 65 of the land has been out of the transfer of a generation of agricultural population, and can be seen in the choice of land outflow, a generation of people mainly concentrated in 1 years, 5 years, 10 years.

TABLE IV. LAND OUTFLOW OF FIXED NUMBER OF YEAR

\begin{tabular}{|l|l|l|l|}
\hline $\begin{array}{c}\text { Outflow period } \\
\text { (unit: year) }\end{array}$ & Sample number & A generation & proportion (\%) \\
\hline 1 & 30 & 20 & 30.77 \\
\hline 2 & 1 & 1 & 1.5 \\
\hline 3 & 7 & 2 & 3 \\
\hline 4 & 1 & 1 & 1.5 \\
\hline 5 & 26 & 13 & 20 \\
\hline 6 & 2 & 2 & 3 \\
\hline 10 & 37 & 17 & 26.15 \\
\hline 12 & 1 & 1 & 1.5 \\
\hline 13 & 2 & 1 & 1.5 \\
\hline 25 & 1 & 1 & 1.5 \\
\hline 30 & 8 & 6 & 9 \\
\hline Other & 4 & 0 & 0 \\
\hline Total & 120 & 65 & 100 \\
\hline
\end{tabular}

The transfer of a generation of agricultural population in 20 only one year of land transfer, probably because they can recover the land at any time to cultivate. Selection of 5 years, 10 years of the contract period of a generation of population, the possible reason is that work is stable, can not have too much to take into account the land.

4) Land out of form: "Table V" shows the statistics of the land out form, 120 of the land has been out of the transfer of agricultural population of 65 is a generation of agricultural transfer population, including 4 items of transfer, subcontract, lease, borrow, in the field visits to the survey found that a generation of agricultural transfer population to the land outflow is mostly used in the form of rent.
TABLE V. LAND OUT OF FORM

\begin{tabular}{|l|l|l|l|}
\hline Outflow form & Sample number & A generation & Proportion (\%) \\
\hline Transfer & 10 & 8 & 12.31 \\
\hline Subcontract & 22 & 9 & 13.85 \\
\hline Lease & 4 & 1 & 1.5 \\
\hline Borrow & 82 & 47 & 72.31 \\
\hline Other & 2 & 0 & 0 \\
\hline Total & 120 & 65 & 100 \\
\hline
\end{tabular}

In 65 of the 47 a generation of agricultural transfer of population chose rent as their land out form, the number of a generation are more than new generation, which may be due to the rental in the form of land outflow in the land to recover more flexible.

5) Land out of expectation: "Table VI" shows a statistics of land out of expectation,120 of the land has been out of the transfer of agricultural population of 65 is a generation of agricultural transfer population, a total of 4 items including now out of circulation will continue to operate after returning to old age, looking forward to the future of property improvement and land value, without regard to their home land, can concentrate on work in the city, other. In the investigation found that a generation of agricultural population transfer of the land is now out of expectation out of old hometown after continue to operate, without regard to their home land.

TABLE VI. LAND OUT OF EXPECTATION

\begin{tabular}{|l|l|l|l|}
\hline \multicolumn{1}{|c|}{ Outflow expectation } & \multicolumn{1}{|c|}{$\begin{array}{c}\text { Sample } \\
\text { number }\end{array}$} & $\begin{array}{c}\text { A } \\
\text { generation }\end{array}$ & $\begin{array}{c}\text { Proportion } \\
(\%)\end{array}$ \\
\hline $\begin{array}{l}\text { Now out of circulation will continue } \\
\text { to operate after returning to old age }\end{array}$ & 34 & 30 & 46.2 \\
\hline $\begin{array}{l}\text { looking forward to the future of } \\
\text { property improvement and land value }\end{array}$ & 41 & 11 & 16.9 \\
\hline $\begin{array}{l}\text { without regard to their home land, can } \\
\text { concentrate on work in the city }\end{array}$ & 43 & 23 & 35.4 \\
\hline Other & 2 & 1 & 1.5 \\
\hline Total & 120 & 65 & 100 \\
\hline
\end{tabular}

Outflow of land now expect out of old hometown after continuous operation for more than 50 years old of the agricultural population transfer, this may be because they have more things to think about to land social security function and are engaged in related industries. Choose do not have to take into account the land of the home more consideration is now working more stable, you can concentrate on work.

\section{B. The New Generation of Agricultural Population Transfer Land Outflow Situation}

1) Land outflow motivation: "Table VII" shows that 55 new generation of agricultural transfer population has been transferred out of the land, In 7 of the increase income, the pursuit of a new way of life, no time to take into account the land management, no interest in agricultural operations, others suggest that the outflow, there is a good policy guidance, etc, the new generation of land outflow tend to choose the pursuit of a new way of life, no interest in agricultural operations, to take into account the land 
management respectively were $11,16,18$,possible reasons as mentioned above, due to the transformation of thinking, the new generation is more the pursuit of quality of life and the realization of self value.

TABLE VII. LAND OUT OF TARGET

\begin{tabular}{|l|l|l|l|}
\hline \multicolumn{1}{|c|}{ Item } & $\begin{array}{l}\text { Sample number } \\
\text { (person) }\end{array}$ & $\begin{array}{l}\text { New generation } \\
\text { (person) }\end{array}$ & $\begin{array}{l}\text { Proportion } \\
(\%)\end{array}$ \\
\hline Increase income & 6 & 2 & 3.64 \\
\hline $\begin{array}{l}\text { The pursuit of a new way of } \\
\text { life }\end{array}$ & 18 & 11 & 16.92 \\
\hline $\begin{array}{l}\text { No time to take into account } \\
\text { the land management }\end{array}$ & 58 & 18 & 27.69 \\
\hline $\begin{array}{l}\text { No interest in agricultural } \\
\text { operations }\end{array}$ & 20 & 16 & 24.62 \\
\hline $\begin{array}{l}\text { Others suggest that the } \\
\text { outflow }\end{array}$ & 3 & 0 & 0 \\
\hline Have good policy guidance & 4 & 1 & 1.82 \\
\hline Other & 11 & 8 & 12.31 \\
\hline Total & 120 & 55 & 100 \\
\hline
\end{tabular}

2) Land outflow object: "Table VIII" shows a statistics of land outflow object, 120 of the land has been out of the transfer of agricultural population of 65 is a generation of agricultural transfer population, including four items of relatives and friends, fellow villagers, village collective, research institutes, large enterprises. Found in the filed visits to the survey that a generation of agricultural population transfer to the basic object of land outflow for relatives and friends.

TABLE VIII. LAND OUTFLOW OBJECT

\begin{tabular}{|l|l|l|}
\hline \multicolumn{1}{|c|}{ Land outflow object } & New generation & Proportion (\%) \\
\hline Relatives and friends & 42 & 76.4 \\
\hline Fellow villagers & 7 & 12.7 \\
\hline village collective & 1 & 1.8 \\
\hline Research institutes and large enterprises & 5 & 9.1 \\
\hline Other & 0 & 0 \\
\hline Total & 55 & 100 \\
\hline
\end{tabular}

There are 80 people's land transfer objects choose relatives and friends, fellow villagers, including new generation of 56 people, which may be because the new generation is not engaged in agricultural activities, land by parents, relatives and friends for generations, Therefore, the object of the outflow of land more choice of relatives and friends.

3) Land outflow of fixed number of year: "Table IX" shows the statistics on the number of years of land outflow of 55 of the land has been out of the transfer of new generation of agricultural population, can be seen in the choice of land outflow period, the new generation mainly concentrated in the 1 years, 5 years and 10 years.
TABLE IX. LAND OUTFLOW OF FIXED NUMBER OF YEAR

\begin{tabular}{|l|l|l|l|}
\hline $\begin{array}{c}\text { Outflow period } \\
\text { (unit: year) }\end{array}$ & Sample number & New generation & Proportion (\%) \\
\hline 1 & 30 & 10 & 18.2 \\
\hline 3 & 7 & 5 & 9.1 \\
\hline 5 & 26 & 13 & 23.6 \\
\hline 10 & 37 & 20 & 36.4 \\
\hline 13 & 2 & 1 & 1.8 \\
\hline 15 & 2 & 2 & 3.6 \\
\hline 20 & 2 & 2 & 3.6 \\
\hline 30 & 8 & 2 & 3.6 \\
\hline Other & 6 & 0 & 0 \\
\hline Total & 120 & 55 & 100 \\
\hline
\end{tabular}

4) Land out of form: "Table X" shows the statistics of the land out form, 120 of the land has been out of the transfer of agricultural population of 55 is new generation of agricultural transfer population, including 5 items of transfer, subcontract, lease, borrow, and other, in the field visits to the survey found that the new generation of agricultural transfer population in the form of land outflow are similar to a generation, mostly used in the form of rent.

TABLE $X$. LAND OUT OF FORM

\begin{tabular}{|l|l|l|l|}
\hline Land out of form & Sample number & New generation & Proportion (\%) \\
\hline Transfer & 10 & 2 & 3.6 \\
\hline Subcontract & 22 & 13 & 23.6 \\
\hline Lease & 4 & 3 & 5.5 \\
\hline Borrow & 82 & 35 & 63.6 \\
\hline Other & 2 & 2 & 3.6 \\
\hline Total & 120 & 55 & 100 \\
\hline
\end{tabular}

5) Land out of expectation: "Table XI" shows the statistics of the situation of land outflow expectation of 55 new generational agricultural transfer population. Including the current out flowing and continuing to operate after back to home in the old age, looking forward the improvement of property rights and land added value in the future, no having to take into account the land of his hometown and they can concentrate on the work of the city, other 4 items. Basic land outflow expectations of the generation of agricultural transfer population found in field visits is improvement of property rights and land value increment in the future, then they can not have to take into account the land of the home and concentrate on the work of the city.

TABLE XI. LAND OUT OF EXPECTATION

\begin{tabular}{|l|l|l|l|}
\hline \multicolumn{1}{|c|}{ Outflow expectation } & $\begin{array}{c}\text { Sample } \\
\text { number }\end{array}$ & $\begin{array}{c}\text { New } \\
\text { generation }\end{array}$ & $\begin{array}{c}\text { Proportion } \\
(\%)\end{array}$ \\
\hline $\begin{array}{l}\text { The current outflowing and continuing to } \\
\text { operate after back to home in the old age }\end{array}$ & 34 & 4 & 7.3 \\
\hline $\begin{array}{l}\text { Looking forward to the future of property } \\
\text { improvement and land value }\end{array}$ & 41 & 30 & 54.5 \\
\hline $\begin{array}{l}\text { Without regard to their home land, can } \\
\text { concentrate on work in the city }\end{array}$ & 43 & 20 & 36.4 \\
\hline Other & 2 & 1 & 1.8 \\
\hline Total & 120 & 55 & 100 \\
\hline
\end{tabular}

They whose land outflow expectation is the improvement of property rights in the future are agricultural transfer 
population between the ages of 20-30 years old. This may be because they take into account property function of the land from more aspects and expects land added value after the improvement of the land property rights in the future. They can choose not to take care of their home land and their more consideration is used to concentrate on work and study.

\section{CONCLUSION}

There are obvious intergenerational differences in the outflow of agricultural transfer population. The two generation of agricultural transfer population has obvious differences in the issue of land outflow. The new generation of agricultural transfer population is more inclined to land outflow than the first generation. Agricultural transfer population outflow significantly affected by family. Land security function for land outflow can not be ignored. When they think more important land endowment security function, the outflow of land is difficult.

\section{REFERENCES}

[1] He Jun, Li Qing. Study on the land transfer behavior of migrant workers from the perspective of intergenerational differences [J]. agricultural technical and economic 2014(01):65-72

[2] Xu Hengzhou Guo Yuyan, Wu Guancen, Jin Jing. Analysis of the influencing factors of migrant workers' willingness to land transfer in the perspective of intergenerational differences: An Empirical Study Based on 613 questionnaires in Tianjin [J]. resources science, 2012(10):1864-1870.

[3] Wang Chunguang. The relationship between the social identity and the integration of urban and rural areas in the new generation of rural migrant population [J]. sociological research, 2001 (3): 63-76

[4] Kong Xiangzhi, Xu ho. Land circulation farmers choose the object factors [J] Chinese rural economy, 2010 (12): 17-25

[5] Zhang Chao, Zhou Yanbo. Analysis of the factors affecting agricultural transfer population from the perspective of intergenerational differences $[\mathrm{J}]$ agricultural economics, 2015 (2): 114-115. 